\title{
片側式リニア誘導モータの拘束試験 に基づく非対称定数算定法
}

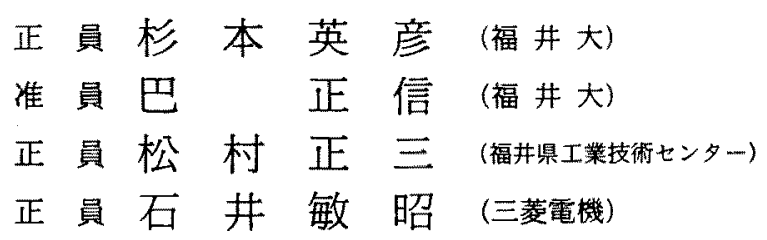

\section{A Method of Calculating Asymmetrical Constants Based on Lock Test for Single-Sided Linear Induction Motor}

Hidehiko Sugimoto, Member, Masanobu Tomoe, Associate (Fukui University), Masami Matsumura, Member (Technical Center of Fukui Prefecture), Toshiaki Ishii, Member (Mitsubishi Electric Coporation)

The constants of each phase of linear induction motor(LIM) are different, because of it's structure. It is important that the method of calculating asymmetrical constants is established, because the asymmetrical constants cause the thrust pulsation. In this paper, a new method of calculating asymmetrical constants of LIM is proposed. Moreover, the results of simulation performed by the calculated constants are compared with the experimental results.

The test machine of LIM is single-sided, short-primary-type, three-phase and 4-poles. The primary winding wires are double layer winding, concentrated winding and full pitch winding. In this paper, first, the asymmetrical equivalent circuits and voltage equations of LIM are showed on suitable $d-q$ axis. Next, the asymmetrical constants are obtained by the calculations based on $d$ axis equivalent no-load test, $q$ axis equivalent no-load test, three-phase equivalent no-load test, $d$ axis lock test and $q$ axis lock test. Here, the equivalent no-load test is the lock test removed the non-magnetic conductor plate from LIM. Finally, it is showed that the simulations results of thrust containing pulsation and primary currents performed by the calculated constants are satisfactorily agreed with experimental results.

キーワード：リニア誘導モータ, 等価回路, 電圧方程式, 非対称定数決定法

\section{1. まえがき}

リニア誘導モータ（以下，LIM と略記）の定数は その構造上, 相によって異なる。定数の相非対称は推 力脈動の原因となるので，それを考虑した定数の算定 法を確立することは重要である。本論文は, 相非対称 である定数の湘定による決定法を提案するものであ る。

定数を測定によって決定する方法は既に幾つか報告
されているが(1) (3)，これらは定数が相対称であると して报っており，相非对称を考慮したものは見あたら ない。本論文は片側式短一次形 LIM を対象とし，そ の定数を，一次巻線の抵抗測定，等価無負荷試験およ び拘束試験の結果から求めるものである。ただし， LIM は一次側中性点引出し線付きとする。ここで等 価無負荷試験というのは, 促来の無負荷試験, すなる ち，同期速度で動かして二次側に電流が流れないよう にするものとは異なり，非磁性導体板を取除いて磁性 
導体板のみで二次側を構成し(4)，拘束状態でも二次側 にほとんど電流が流れないようにすることて，等価的 に無負荷状態にする試験である。従って，本論文で提 案する方法はLIM を拘束したままの試験で定数を決 定することができる。ただし，対象は低速 LIM と し，端効果は無視できるものとする。

相非対称を考慮した片側式短一次形 LIMの定数を 測定によって決定するために，まず非対称等価回路お よび電圧方程式を求める必要がある。それらをLIM の構造を考慮して選んだ $d q$ 軸上で，鉄損等価抵抗も 含めて表す。ただしこれらに含まれる相互インダタ タンスの值を測定によって決定するためには，等価無 負荷状態の三相等価回路拉よび電圧方程式も必要で, その式中に現れる結合係数をLIM の構造から決定す る。 $d q$ 軸上で表される LIM の各定数は，一次巻線の 抵抗測定の後, $d$ 軸, $q$ 軸および相の等価無負荷試 験, $d$ 軸およぴ $q$ 軸の拘束試験の合計 5 回の試験で すべて決定できる。定数の周波数依存性は印加電圧の 周波数を変える試験で調べることがきる。

算定された定数の精度を検証するために，その定数 を使って，三相電王を印加した拘束時の一次電流およ び推力をシミェレーションで求め，同じ条件下の実験 結果と比較している。それらの差は, 非対称定数に起 因して現れる推力脈動を含めて小さく，本論文で提案 する定数の算定法は有用であると考えられる。

\section{2.リニア誘導モータの構造と等価回路・電圧} 方程式

〈2・1〉楆造 供試LIMは, 図1に示すよ うに片側式短一次形で，三相 4 極である。一次巻は二 線層巻・集中巻・全節巻で，その配置は図のと扔りで あり，またその巻数は各相同じである。二次側は非磁 性嵮体板であるアルミニウム板と磁性導体板である鉄 板で構成されている。このような粠造の場合，低速で 使用し，端効果が無視できるとすると， $v$ 相と $w$ 相 の一次巻線は自己，相互誘䢙回路とも対稳である。し かし， $u$ 相一次巻線の自己回路はそれらと対称である が，相互誘導回路はそれらと対称とならない。このこ

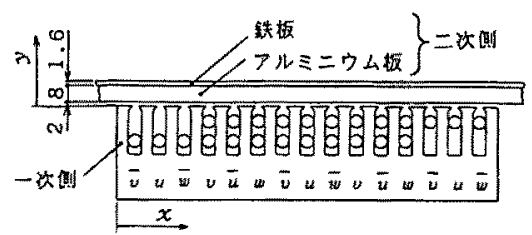

図 1 供試 LIM の構造

Fig. 1. Structure of test machine.
とは, 後載の図 $9(b)$, 図 $10(b)$ に示した等価無負 荷状態拉上び拘束状態の三相一次電流実酸波形からも わかる。その非対称性は極数が少ないほど顈著であ る。供試 LIM は 4 極で，非対称性が比較的大きいと 予想される。な奶このLIMの一次巻線には中性点 引出線がついている。

表 1 に供試 LIM の仕様をまとめる。

〈2・2〉等価回路 I 図 1 の構造を有するLIM の等価回路について考无る。一次側は巻線が巻かれて おり，その電流路が決まっているが，二次側は瀜電流 が流れ，その電流路が状態によって変化する。しか し，その電流は二次側に設定した二つの任意の軸上に とった電流路へ座標変換が可能である。そして，一次 側についても同じことがいえる。

そこて，LIM の等価回路を，回転形誘遭電動機と 同様，座標変換して $d q$ 軸上で表すことにする。 $d q$ 軸は一次側に固定された座標で，一次，二次ともこれ らの軸上に巻線があると考える。図 2 は $d q$ 軸で表し

\section{表 1 供試機の仕様}

Table 1. Specification of test machine.

\begin{tabular}{|c|c|c|c|}
\hline \multicolumn{2}{|c|}{ 定抬 } & スロットヒッチ & $\sin$ \\
\hline 要压一筧满 & $200 \mathrm{~V}-4.4 \mathrm{~A}$ & エアーーギャッフ & $2 \mathrm{~mm}$ \\
\hline 周波敨 & $60 \mathrm{~Hz}$ & \multicolumn{2}{|c|}{ 一地 } \\
\hline 灌力 & $40 \mathrm{~N}$ & 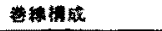 & $=\pi t$ \\
\hline Ev & $4 P$ & 大政里 & 1 \\
\hline 同期逞安 & $4.68 \mathrm{~m} / \mathrm{s}$ & \multicolumn{2}{|c|}{$=$ 体 } \\
\hline \multicolumn{2}{|c|}{ 一次战心(ギャッブ面の寸法) } & 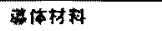 & ナルミ \\
\hline \%心 & $202 \mathrm{~mm}$ & 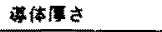 & $8 \mathrm{mog}$ \\
\hline 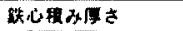 & $50 \mathrm{~m} \mathrm{~m}$ & 慗体桠 & $150 \mathrm{~mm}$ \\
\hline 聕ビッキ & $39 \mathrm{~mm}$ & 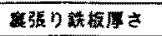 & $1.6 \mathrm{~mm}$ \\
\hline 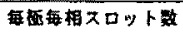 & 1 & 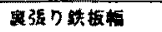 & $150 \mathrm{mII}$ \\
\hline
\end{tabular}

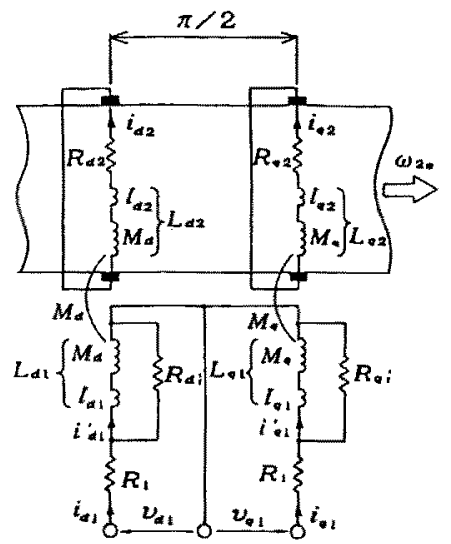

図 $2 d q$ 軸で表したLIMの等価回路 Fig. 2. Equivalent circuit of LIM on $d q$ axis. 
た LIM の等価回路である。 $d$ 軸を一次側の $u$ 相と一 致させ, $q$ 軸をその軸より $\pi / 2$ だけ進めてとる。 $d q$ 軸をこのように選ぶのは, LIM の粠造を考虑して, 一次電流を $d$ 軸のみ，あるいは $q$ 軸のみに流すよう な試験に対応できるようにするためでる。なお，二次 側の巻線は二次側とともに移動して行くが，電流が流 れる巻線は常に $d q$ 軸上にある。

この図 2 において，R1は一次抵抗であり, 三相一 次巻線の相抵抗が各相同じなので $d, q$ 軸で差がない。 $R_{d i}, R_{q i}$ は $d, q$ 軸鉄損等価抵抗であり，それらの接 続位置は $\pi$ 形等価回路(5) と同じである。漏れインダ クタンスの中にも鉄損を生じるものがあるが，LIM は等価空䏚長が長いので，その一つである霜端漏れイ ンダクタンスの占める割合が大きいと考えられ，鉄損 等価抵抗をこの位置に接続することは妥当といえる。 $R_{d 2}, R_{q 2}$ は $d, q$ 軸二次抵抗である。 $L_{d 1}, L_{q 1}$ は $d, q$ 軸一次自己インダクタンス, $L_{d 2}, L_{q 2}$ は $d q$ 軸二次自 己インダタンス, $M_{d}, M_{q}$ は $d, q$ 軸相互インダクタン スで, $l_{d 1}, l_{q 1}$ を $d, q$ 軸一次漏れインダクタンス, $l_{d 2}$, $l_{q 2}$ を $d, q$ 軸二次漏れインダクタンスとすると,

$$
\left.\begin{array}{l}
L_{d 1}=l_{d 1}+M_{d} \\
L_{q 1}=l_{q 1}+M_{q} \\
L_{d 2}=l_{d 2}+M_{d} \\
L_{q 2}=l_{q 2}+M_{q}
\end{array}\right\}
$$

の関係がある。 $v_{d 1}, v_{q 1}$ は $d, q$ 軸一次電圧, $i_{d 1}, i_{q 1}$ は $d, q$ 軸一次電流， $i_{d 1,}^{\prime}, i_{q 1}^{\prime}$ は $i_{d 1}, i_{q 1}$ 加鉄損等価抵抗 に流れる電流を差し引いた $d, q$ 軸一次電流, $i_{d 2}, i_{q 2}$ は $d, q$ 軸二次電流である。角速度（電気的） $\omega_{2 e}$ は, 二次側の速度（機械的）を $v_{2 m}$ ，極ピッチを $\tau$ とする と，次の関係がある。

$$
\omega_{2 e}=(\pi / \tau) v_{2 m}
$$

等価回路として三相等価回路も描ける。後述する定 数の算定において必要な無負荷状態の三相等価回路を 図 3 に示す。無負荷状態であるのて，二次側には電流

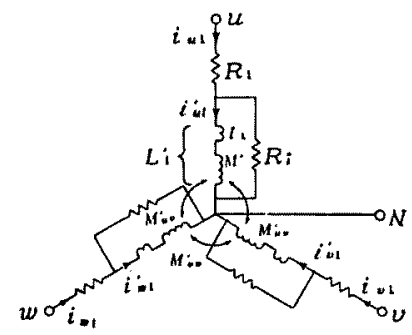

図 3 無負荷状態の三相等価回路

Fig. 3. Three-phase equivalent circuit under no-load state.
が流れないものとし，二次側は考えない。

各相の自己回路は，その構造上三相対称てあり，相 互誘導回路は $v$ 相と $w$ 相とは対称であるが，それら と $u$ 相とは非対称である。図 3 はこのことを考虑し て示してある。図中， $R_{1}$ は相一次抵抗， $R_{i}$ は相鉄損 等価抵抗である。 $L_{1}^{\prime}$ は一次自己インダクタンスで, $M^{\prime}$ を $L_{1}^{\prime}$ 中の相互インダクタンス分, $l_{1}$ を $L_{1}^{\prime}$ 中の漏 れインダクタンス分とすると，

$$
L_{1}^{\prime}=l_{1}+M^{\prime}
$$

である。 $M_{u v}^{\prime}, M_{v w}^{\prime}$ は $u$ 相と $v$ (または $\left.w\right)$ 相巻線間 および, $v$ 相と $w$ 相巻線間の相互インダクタンスで ある。 $M^{\prime}, M_{u v}^{\prime}, M_{v w}^{\prime}$ には次の関係がある。

$$
\begin{aligned}
& M_{u v}^{\prime}=k_{u v} M^{\prime} \\
& M_{v w}^{\prime}=k_{v w} M^{\prime} \\
& \text { ここに, } k_{u v}, k_{v w} \text { : 結合係数 }
\end{aligned}
$$

〈2・3〉 電圧方程式と推力の式 図 2 から非対称 を考慮した $d q$ 軸上での電圧方程式が得られ, 次式で 表される。

$$
\begin{aligned}
{\left[\begin{array}{c}
v_{d 1} \\
v_{q 1} \\
0 \\
0
\end{array}\right]=} & {\left[\begin{array}{cc}
R_{1}+k_{d} P L_{d 1} & 0 \\
0 & R_{1}+k_{q} P L_{q 1} \\
P M_{d} & \omega_{2 e} M_{q} \\
-\omega_{2 e} M_{d} & P M_{q} \\
k_{d} P M_{d} & 0 \\
0 & k_{q} P M_{q} \\
R_{d 2}+P L_{d 2} & \omega_{2 e} L_{q 2} \\
-\omega_{2 e} L_{d 2} & R_{q 2}+P L_{q 2}
\end{array}\right]\left[\begin{array}{c}
i_{d 1}^{\prime} \\
i_{q 1}^{\prime} \\
i_{d 2} \\
i_{q 2}
\end{array}\right] }
\end{aligned}
$$

ここで, $P(=d / d t)$ 坆微分演算子であり， $k_{d}, k_{q}$ は鉄 損等洒抵抗を考慮するときに必要な係数で，次で表さ れる (付録参照)。

$$
\left.\begin{array}{l}
k_{d}=1+R_{1} / R_{d i} \\
k_{q}=1+R_{1} / R_{q i}
\end{array}\right\}
$$

なお， $i_{d 1}$ と $i_{d 1}^{\prime}, i_{q 1}$ と $i_{q 1}^{\prime}$ の間にはそれぞれ次の関 係がある。

$$
\left.\begin{array}{l}
i_{d 1}=\frac{1}{k_{d}}\left(i_{d 1}^{\prime}+\frac{v_{d 1}}{R_{d i}}\right) \\
i_{q 1}=\frac{1}{k_{q}}\left(i_{q 1}^{\prime}+\frac{v_{q 1}}{R_{q i}}\right)
\end{array}\right\}
$$

また，図2において推力 $T_{e}$ は次式で表される。

$$
\begin{aligned}
T_{e}= & \frac{\pi}{\tau}\left\{M_{q} i_{q 1}^{\prime} i_{d 2}-M_{d} i_{d 1}^{\prime} i_{q 2}\right. \\
& \left.+\left(L_{q 2}-L_{d 2}\right) i_{d 2} i_{q 2}\right\}
\end{aligned}
$$

一方, 図 3 加ら二次電流が 0 の場合の三相等価回路 の電圧方程式が得られ，次式で表される。 


$$
\begin{aligned}
& {\left[\begin{array}{c}
v_{u 1} \\
v_{v 1} \\
v_{w 1}
\end{array}\right]=\left[\begin{array}{cc}
R_{1}+k_{1} P L_{1}^{\prime} & k_{1} P M_{u v}^{\prime} \\
k_{1} P M_{u v}^{\prime} & R_{1}+k_{1} P L_{1}^{\prime} * \\
k_{1} P M_{u v}^{\prime} & k_{1} P M_{v w}^{\prime}
\end{array}\right.} \\
& \left.\begin{array}{cc}
k_{1} P M_{u v}^{\prime} \\
R_{1}+k_{1} P M_{1}^{\prime}
\end{array}\right]\left[\begin{array}{l}
i_{u 1}^{\prime} \\
i_{v 1}^{\prime} \\
i_{w 1}^{\prime}
\end{array}\right]
\end{aligned}
$$

ここで，k $k_{1}$ は鉄損等価抵抗を考慮するときに必要 な係数で，次式で表される (付録参照)。

$$
k_{1}=1+R_{1} / R_{i}
$$

なお， $i_{v 1}$ と $i_{v 1}^{\prime}$ の間には次の関係がある。

$$
i_{v 1}=\frac{1}{k_{1}}\left(i_{v 1}^{\prime}+\frac{v_{v 1}}{R_{i}}\right)
$$

$i_{u 1}$ と $i_{u 1}^{\prime}, i_{w 1}$ と $i_{w 1}^{\prime}$ の関係も同様である。ところで， (5)，(9)式で表されるインダクタンスの間には次の 関係がある。

$$
\begin{gathered}
{\left[\begin{array}{l}
k_{d} L_{d 1} \\
k_{q} L_{q 1}
\end{array}\right]=[C] k_{1}\left[\begin{array}{lll}
L_{1}^{\prime} & M_{u v}^{\prime} & M_{u v}^{\prime} \\
M_{u v}^{\prime} & L_{1}^{\prime} & M_{v w}^{\prime} \\
M_{u v}^{\prime} & M_{v w}^{\prime} & L_{1}^{\prime}
\end{array}\right][C]^{-1}} \\
\ldots \ldots \ldots \ldots \ldots \ldots \ldots \ldots \ldots \ldots \ldots \ldots \ldots \ldots \ldots \ldots \\
{\left[\begin{array}{l}
k_{d} M_{d} \\
k_{q} M_{q}
\end{array}\right]=[C] k_{1}\left[\begin{array}{lll}
M^{\prime} & M_{u v}^{\prime} & M_{u v}^{\prime} \\
M_{u v}^{\prime} & M^{\prime} & M_{v w}^{\prime} \\
M_{u v}^{\prime} & M_{v w}^{\prime} & M^{\prime}
\end{array}\right][C]^{-1}}
\end{gathered}
$$

ここに,

$[C]=\sqrt{2 / 3}\left[\begin{array}{ccc}1 & -1 / 2 & -1 / 2 \\ 0 & \sqrt{3} / 2 & -\sqrt{3} / 2\end{array}\right]$.

また， $d q$ 軸上および三相で表される一次電圧，一 次電流の間には次の関係がある。

$$
\left[\begin{array}{ll}
d 1 & q 1
\end{array}\right]^{t}=[C]\left[\begin{array}{lll}
u 1 & v 1 & w 1
\end{array}\right]^{t}
$$

〈2・4〉等価回路 I (5)式から得られる等価回 路注図 4 (a)，（b）に表される $\pi$ 形等価回路である。 図中 $の, \lambda_{d 2}, \lambda_{q 2}$ は $d, q$ 軸二次鎖交磁束数 $\urcorner$,

$$
\left.\begin{array}{l}
\lambda_{d 2}=M_{d} i_{d 1}^{\prime}+L_{d 2} i_{d 2} \\
\lambda_{q 2}=M_{q} i_{q 1}^{\prime}+L_{q 2} i_{q 2}
\end{array}\right\}
$$

である。

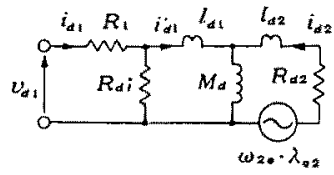

(a) $d$ 軸

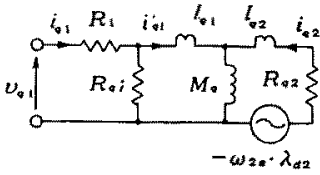

(b) $q$ 触
図 $4 d q$ 軸における $\pi$ 形等価回路

Fig. 4. $\pi$-type equivalent circuit on $d q$ axis.

\section{3. 定数の算定}

〈3・1〉無負荷試験について LIM は非磁性罗体 板を簡単に取外すことができる。そこで，二次側を 性導体板のみとする。ただ，等価空䧆長は非磁性章 体板がある場合と同じに保つ。このとき一次巻線に通 電しても，磁性導体板には電流がほとんど流れないの で，拘束したままで等価的に無負荷と等しい状隹を作 ることができる。実際の無負荷状態とは漂遊角荷損が 若干異なると考えられるが，その差は小さく無視でき るものとする。そこで，このような状態で試験するこ とを等価無負荷試験と呼ふことにする。

〈3.2〉 磁気的和について LIM の定数の算定に おいて磁気飽和は愦差の原因となる。をこで磁気飽和 について調べることにする。

図 5 は，供試 LIM を等価無負荷状態にし，定格周 波数 $(60 \mathrm{~Hz})$ の $d, q$ 軸一次電压を, 後述の図 8 (a)，（b）に示すように，別及に印加して一次電㐬を 流し，それぞれの実效值 $V_{d 1}, V_{q 1}, I_{d 1}$ 扝よび $I_{q 1}$ の関 係を調べたものである。電圧と電流の関係は電圧を定 格值 $\left(v_{d 1}, v_{q 1}\right.$ の定格実効值はともに $\left.141 \mathrm{~V}\right)$ まで変化 させても直線的で磁気飽和はほとんど見られない。 LIM は等価空吵長が長く, 励磁回路の飽和は少ない といわれているが, 図 5 はその様子を示している。

(3.3) 結合係数 $\boldsymbol{k}_{u v}, \boldsymbol{k}_{v w}$ について （4）式で定 義した結合倸数 $k_{u v}, k_{v w}$ を，等洒無負荷状態で，一相 の一次巻線に電流を流し，他相の一次巻線に誘迸され る起電力を測定することで，算定する方法について考 える。その手順を以下に述べる。

（1）供試 LIM を等価無負荷状態とし, 後载の図 8（c）に示すように，滋をを流す。それを流すのは， (9)，(11)式からわかるように，一度の試験で $k_{u v}$ と

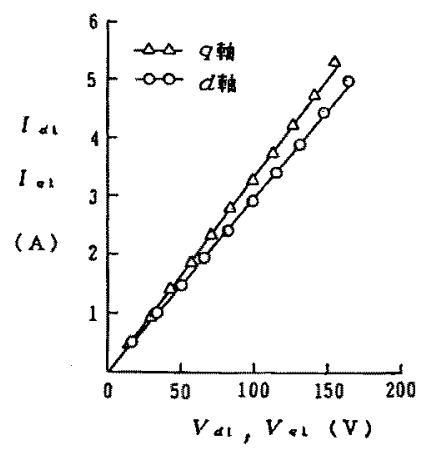

図 $5 d$ 軸と $q$ 軸における等価無負荷 武験結果

Fig. 5. Result of equivalent no-load test on $d q$ axis. 
kvw のつが算定できるからである。このとき $(4)$ ， (9)式より次の式が得られる。

$$
\left.\begin{array}{l}
v_{v 1}=\left\{R_{1}+k_{1} P\left(l_{1}+M^{\prime}\right)\right\} i_{v 1}^{\prime} \\
v_{u 1}=k_{1} P M_{v v}^{\prime} i_{v 1}^{\prime}=k_{1} P k_{u v} M^{\prime} i_{v 1}^{\prime} \\
v_{w 1}=k_{1} P M_{v w}^{\prime} i_{v 1}^{\prime}=k_{1} P k_{v w} M^{\prime} i_{v 1}^{\prime}
\end{array}\right\}
$$

ここに, $v_{u 1}, v_{w 1}$ は $u$ 相， $w$ 相の $M^{\prime} i_{v 1}^{\prime}$ による誘導 起電力であり, 測定できる。

なお， $i_{v 1}$ の代わりに $i_{w 1}$ を流してもよい。

（2）磁気回路から, $M^{\prime} i_{v 1}^{\prime}$ の図 1 の $y$ 方向の波形 (以下, $M^{\prime} i_{v 1}^{\prime}$ と略記) を検討する。それは，図 1 の $x$ 方向に $2 \tau$ を 1 周期とする対称で奇関数の波形であ り，4極であるから 2 周期分ある。図 6(a)，(b)は それを示している。これらの図は等価無負荷状態で, $u$ 相捛よび $v$ 相一次巻線に 4.1 A (等価無負荷状態で 定格相一次電圧を印加したとき流れる実効值) の直流 電流を別々に流し，図1において，鉄心積み厚さ方向 の中心で, $y=6 \mathrm{~mm}$ の位置の $y$ 方向磁束密度分布を $x$ 方向に測定したものである。二つの波形は $2 \pi / 3$ 位 相がずれた対称波で，それぞれ $2 \tau$ を 1 周期とする対 称で奇関数の波形で， 2 周期分ある。ほほ台形波にな っているのは等価空隙長が長いためと考えられる。波 形の端部が延びているが，それはわずかである。

（3）各相一次巻線の有無を1，0で，向きを土で 表す。図 7 は供試 LIM についてそれを表したもので

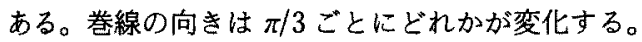

（4） $M^{\prime} i_{v 1}^{\prime}$ 波形を，図 7 に示すように $\pi / 3$ ごとに 区切る。波形が対称で奇関数であるから，区間 $\pi / 3$ $\sim 2 \pi / 3$ の面積を $\phi_{0}$, 区間 $0 \sim \pi / 3$ の面積を $s \phi_{0}$ とする と, $\pi / 3$ ごとの面積は, 順に $s \phi_{0}, \phi_{0}, s \phi_{0},-s \phi_{0},-\phi_{0}$, $-s \phi_{0}, s \phi_{0}, \phi_{0}, s \phi_{0},-s \phi_{0},-\phi_{0},-s \phi_{0}$ となる。

（5） $M^{\prime}$ と $M_{u \nu}^{\prime}$ と $M_{v w}^{\prime}$ の比は, $M^{\prime} i_{\nu 1}^{\prime}$ の $x$ 方向 の波形に $v$ 相, $u$ 相, $w$ 相一次巻線の有無および向 き $( \pm 1,0)$ を掛けた後, それぞれ $x$ 方向に積分して得

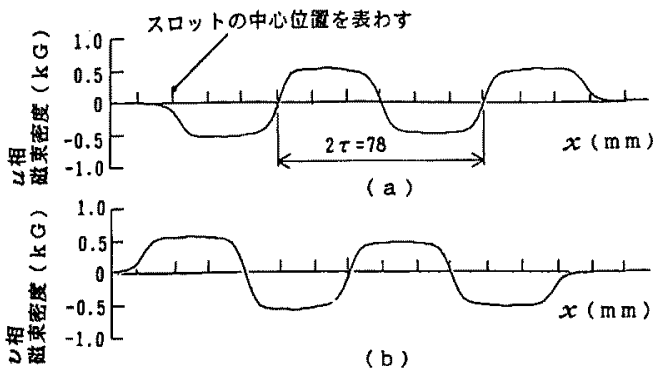

図 6 等価無负荷状態における磁束密度分布 Fig. 6. Distribute of magnetic-flux density under equivarent no-load state.
られる面積に比例する。

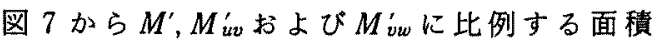
$\Phi\left(M^{\prime}\right), \Phi\left(M_{u v}^{\prime}\right)$ および $\Phi\left(M_{v w}^{\prime}\right)$ は，

$$
\left.\begin{array}{l}
\Phi\left(M^{\prime}\right)=4 \phi_{0}(1+2 s) \\
\Phi\left(M_{u v}^{\prime}\right)=-\phi_{0}(4+s) \\
\Phi\left(M_{v w}^{\prime}\right)=-\phi_{0}(3-s)
\end{array}\right\}
$$

となる。このとき，

$$
\begin{aligned}
v_{u 1}: v_{w 1} & =\Phi\left(M_{u v}^{\prime}\right): \Phi\left(M_{v w}^{\prime}\right) \\
& =4+s: 3-s \cdots \cdots \cdots
\end{aligned}
$$

の関係が成り立つので,

$$
s=\left(3 v_{u 1}-4 v_{w 1}\right) /\left(v_{u 1}+v_{w 1}\right)
$$

となり, 次の関係が得られる。

$$
\left.\begin{array}{l}
k_{u v}=-(4+s) /\{4(1+2 s)\} \\
k_{v w}=-(3-s) /\{4(1+2 s)\}
\end{array}\right\}
$$

（6）上記では三相一次巻線の一相だけ電流を流し $k_{u v}, k_{v w}$ を求めた。LIM を駆動するときは，同時に三 相電圧を印加するので各相起磁力が合成され，各相起

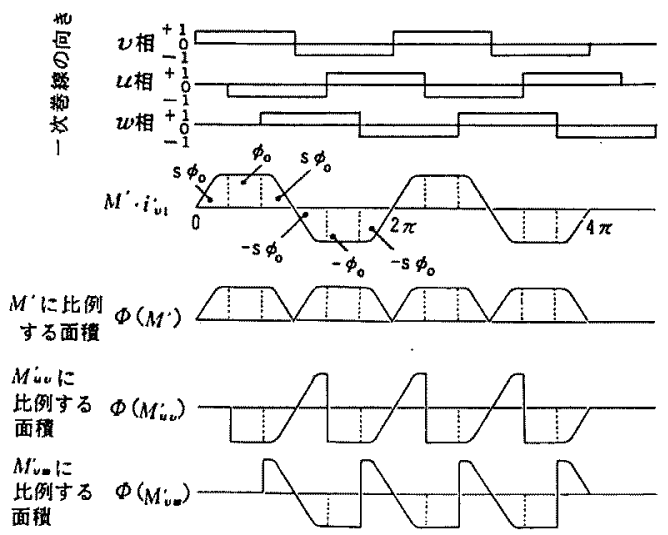

図 7 磁束密度分布と巻線方向による 結合係数の算定

Fig. 7. Calculation of coupled inductors with magnetic-flux density and winding direction.
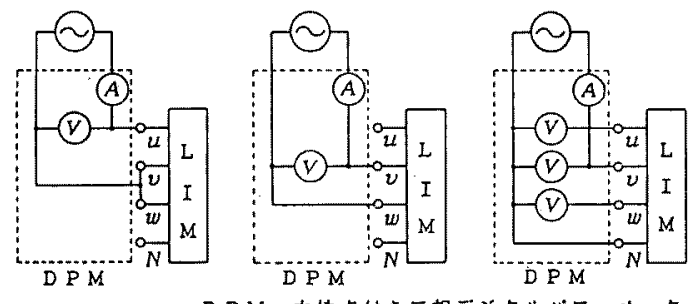

(a) d 舵 D P M : 中性点付き榅デジタバワーメータ

(b) $q$ 軸

(c) $v$ 軸

図 8 試験回路

Fig. 8. Test circuit. 
磁力中の $3 n$ 次の一部が相殺される。従って, $3 n$ 次 が多く含まれていると，上記で求めた $k_{u v}, k_{v w}$ を補正 する必要が生じる。しかし, 供試 LIM の場合， $d$ 軸 および $q$ 軸等価無負荷試験から算定した $L_{d 1}$ と $L_{q 1}$ は, $v$ 相等価無負荷試験を行い(12)式から算定したそ れらと 1〜3\%の差しかなく，一相だけ一次電流を流 した場合も $3 n$ 次が少ないとみることができ, 補正す る必要はないと考える。

〈3.4〉等価無負荷試験 一次抵抗測定後等価無 負荷試験を行う。この試験は, 非磁性導体板を取外 し, 拘束状態て $d$ 軸, $q$ 軸おうよ゙ $v$ 相一次電圧を 別々に印加して行い, 鉄損等価抵抗，一次自己インダ クタンスおよび相互インダクタンスを算定するもので ある。

（1） $d$ 軸等価無負荷試験 図 8（a）に示す試験 回路に抢いて, 電圧, 電流の実効值を $V_{u v}, I_{u 1}$ とす る。 $v$ 相と $w$ 相が対称であることを考慮すると(15) 式より， $V_{d 1}=\sqrt{2 / 3} V_{u v}, V_{q 1}=0, I_{d 1}=\sqrt{3 / 2} I_{u 1}, I_{q 1}=0$ となり，この試験回路で $d$ 軸のみに電圧を印加し電 流を流す試験ができる。 $V_{d 1}, I_{d 1}$ および有効電力 $P_{d 1}$, 角周波数 $\omega$ を用い, 図 4 (a) から次の定数が算定で きる。

(i ) $d$ 軸鉄損等価抵抗

$$
R_{d i}=R_{d n}-R_{1}+\frac{\omega^{2} L_{d n}^{2}}{R_{d n}-R_{1}}
$$

（ii） $d$ 軸一次自己インタククタンス

$$
\begin{aligned}
& L_{d 1}=L_{d n}+\frac{\left(R_{d n}-R_{1}\right)^{2}}{\omega^{2} L_{d n}} \\
& \text { ここに, } \\
& R_{d n}=P_{d 1} / I_{d 1}^{2} \\
& L_{d n}=\sqrt{\left(V_{d 1} / I_{d 1}\right)^{2}-R_{d n}^{2}} / \omega
\end{aligned}
$$

（2） $q$ 軸等価無負荷試験 図 $8(b)$ k示す試験 回路において, 電圧, 電流の実効值を $V_{v w}, I_{v 1}$ とす る。 $v$ 相と $w$ 相が対称であることを考慮すると(15) 式より, $V_{d 1}=0, V_{q 1}=\sqrt{1 / 2} V_{v w}, I_{d 1}=0, I_{q 1}=\sqrt{2} I_{v 1}$ と なり,この試験回路で $q$ 軸のみに電圧を印加し電流 を流す試験ができる。 $V_{q 1}, I_{q 1}$, 有効電力 $P_{q 1}$, 角周波 数 $\omega$ を用い, 図 $4(\mathrm{~b})$ 加ら $d$ 軸等価無負荷試験と同 様, (i) $q$ 軸鉄損等価抵抗，(ii) $q$ 軸一次自己イン ダクタンスを求めることができる。それらは(22) 〜 (25) 式中の添え字 $d$ を $q$ に置き換えることで算定 できる。

（3） $v$ 相等価無負荷試験 図 $8(\mathrm{c})$ に示寸試験 回路において等価無負荷状態での, $v$ 相一次電圧, 電 流， $u$ 相および $w$ 相誘導起電力の実効值を $V_{v 1}, I_{v 1}$,
$V_{u 1}, V_{w 1}$, 有効電力を $P_{v 1}$, 角周波数を $\omega$ とすると, 図 3 から $d$ 軸等価無負荷試験と同様, (i) 相鉄損等 価抵抗, ‘(ii) 相一次自己インダクタンスを求めること ができる。それらは(22)〜 (25)式中の添え字 $d$ をv に置き換えることで算定できる。更に，

(iii) $u$ 相と $v$ 相の間の相互インダクタンス

(17)式より，

$$
M_{u v}^{\prime}=V_{u 1} /\left(k_{1} \omega I_{v 1}^{\prime}\right)
$$

(iv) $v$ 相と $w$ 相の間の相互インダクタンス

(17)式より,

$$
M_{v w}^{\prime}=V_{w 1} /\left(k_{1} \omega I_{\nu 1}^{\prime}\right)
$$

ここに,

$$
\begin{aligned}
& P_{v i}=P_{v 1}-R_{1} I_{v 1}^{2} \ldots \ldots \ldots \ldots \ldots \ldots \ldots \ldots \ldots \ldots \\
& V_{v m}=\sqrt{V_{v 1}^{2}+\left(I_{v 1} R_{1}\right)^{2}-2 R_{1} P_{v 1}} \\
& I_{v 1}^{\prime}=\sqrt{I_{v 1}^{2}+\left(V_{v m} / R_{1}\right)^{2}-2\left(P_{v i} / R_{i}\right)} \cdots
\end{aligned}
$$

以上 $(1) \sim(3) の$ 第価無負荷試験の定数算定值を用 いて,

(i) 相一次インダクタンス中の相互インダクタン ス分は (4)式を変形して, 次のどちらかの式で算定す る。

$$
\left.\begin{array}{l}
M^{\prime}=M_{u v}^{\prime} / k_{u v} \\
M^{\prime}=M_{v w}^{\prime} / k_{v w}
\end{array}\right\}
$$

(ii） $d$ 軸相互インダクタンス, (iii) $q$ 軸相互イ ンダクタンスは(13)式より算定できる。

なお，前述したように $d$ 軸と $q$ 軸の一次自己イン ダクタンスは(12)式からも算定できる。これらの值と 上記 ( 1 ) 項 (ii) および (2) 項 (ii) で算定した值は一致 することが望ましいが，結合係数 $k_{u v}, k_{v w}$ の算定過程 で, $3 n$ 次の空間高調波磁束を無視したので若干の差 が生じ，(12)式で求めたもののほうが 1〜3\%大きか った。 $d$ 軸と $q$ 軸の一次自己インダクタンスは上記 (1)項 (ii)および (2)項 (ii)で算定した值のほうが正 しいと考えられるので，それを採用することにする。

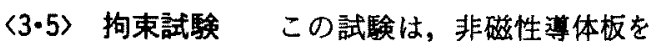
取付け，拘束状態で $d$ 軸および $q$ 軸一次電圧を別々 に印加して行い，二次抵抗，二次自己インダクタンス を算定するものである。

（1） $d$ 軸拘束試験 図 8 (a) に示寸試験回路に おいて, 電圧, 電流の㬰効值を $V_{d 1}, I_{d 1}$, 有効電力を $P_{d 1}$, 角周波数を $\omega$ とすると, 図 4 (a) から次の定数 が算定できる。

(i) $d$ 軸二次抵抗

$$
R_{d 2}=\frac{\omega^{2} M_{d}^{2} R_{d L}}{R_{d L}^{2}+\omega^{2}\left(L_{d 1}-L_{d L}\right)^{2}}
$$

(ii) $d$ 軸二次自己インダクタンス 


$$
L_{d 2}=\frac{\omega^{2} M_{d}^{2}\left(L_{d 1}-L_{d L}\right)}{R_{d L}^{2}+\omega^{2}\left(L_{d 1}-I_{d L}\right)^{2}}
$$

ここに,

$$
\begin{aligned}
& P_{d i}=P_{d 1}-R_{1} I_{d 1}^{2} \\
& V_{d m}=\sqrt{V_{d 1}^{2}+\left(I_{d 1} R_{1}\right)^{2}-2 R_{1} P_{d 1}} \\
& I_{d 1}^{\prime}=\sqrt{I_{d 1}^{2}+\left(V_{d m} / R_{d i}\right)^{2}-\left(2 P_{d i} / R_{d i}\right)} \\
& R_{d L}=\frac{P_{d i}-\left(V_{d m}^{2} / R_{d i}\right)}{I_{d 1}^{\prime}{ }^{2}} \\
& L_{d L}=\sqrt{\left(V_{d m} / I_{d 1}^{\prime}\right)^{2}-R_{d L}^{2}} / \omega
\end{aligned}
$$

（2） $q$ 軸拘束試験 図 8（b)k示す試験回路に おいて, 電王, 電流の実効值を $V_{q 1}, I_{q 1}$, 有効電力を $P_{q 1}$, 角周波数を $\omega$ とすると, 図 $4(\mathrm{~b})$ から $d$ 軸拘束 試験と同様，（i ～$q$ 軸二次抵抗，(ii) $q$ 軸二次自己 インダクタンスを求めることができる。それらは, (32)〜(38)式中の添え字 $d$ をq置き換えることで 算定できる。

\section{4. 算定結果}

第 3 章で述べた算定式に基づき定数を求める。条件 は次のとおりである。

（1） $\omega$ を定格值である $120 \pi(\mathrm{rad} / \mathrm{s})(60 \mathrm{~Hz}), V_{d 1}$ あるいは $V_{q 1}$ を定格値である $141 \mathrm{~V}$ ，あるいは $V_{v 1}$ を 定格值である $115 \mathrm{~V} と し て ，(\mathrm{i}) d$ 軸等価無負荷試 垔，（ii） $q$ 軸等価無負荷試験，（iii） $v$ 相等価無負荷 試験，(iv） $d$ 軸拘束試験，（v） $q$ 軸拘束試験を行う。

(2) $\omega$ を $80 \pi(\mathrm{rad} / \mathrm{s})(40 \mathrm{~Hz}) と し,(1)$ 項と同様 な試験を行う。ただし，電圧は一次電流が(1) 項の各 試験において測定された值になるように印加する。

算定結果を表 2 にまとる。試験時は，一次巻線お よび非磁性導体板の温度を熱電対温度計で測定してお り，表 2 にはその温度も示してある。同表で特徵的な

\begin{tabular}{|c|c|c|c|c|}
\hline 周波 & \multicolumn{2}{|c|}{$40 \mathrm{~Hz}_{\mathrm{Z}}$} & \multicolumn{2}{|c|}{$\mathrm{6OHz}$} \\
\hline & $d \boldsymbol{A}$ & Q 輤 & d辝 & 唃 \\
\hline 一次聕挤 $\left(68^{\circ} \mathrm{C}\right)$ & \multicolumn{4}{|c|}{$R_{1}=5.98 \Omega$} \\
\hline 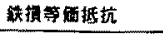 & $R_{d I}=501 \Omega$ & $R_{.} i=560 \Omega$ & $R_{u i}=806 \Omega$ & $R_{.} i=1010 \Omega$ \\
\hline 三次恬抗 $\left(50^{\circ} \mathrm{C}\right)$ & $R_{\mathrm{d} \mathrm{z}}=10.7 \Omega$ & $R_{42}=12.60$ & $R_{\mathrm{da}}=11.2 \Omega$ & $R_{a x}=12.8 \Omega$ \\
\hline 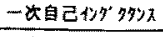 & $L_{\alpha 3}=84.7 \pm \mathrm{H}$ & $L_{a .1}=77.50 \mathrm{H}$ & $L_{\text {as }}=B A$. Imil & $L+1=77.1 \mathrm{~m}$ \\
\hline 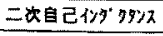 & $L_{\alpha 2}=67 . \partial_{\text {at }}$ & $L_{0.2}=58.8 \mathrm{pH}$ & $L_{1}=85.2$ aff & $L+2=53.9 \mathrm{ath}$ \\
\hline 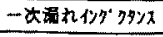 & $l_{\alpha 1}=45.2 \mathrm{WH}$ & $l_{12}=46.38 \mathrm{H}$ & $l_{\mathrm{at}}=44.7 \mathrm{aH}$ & $l .1=46.0 \mathrm{mH}$ \\
\hline 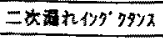 & $t_{\alpha z}=28.5 a \mathrm{H}$ & $l_{.22}=27.6 \mathrm{nH}$ & $l_{\Delta 2}=25.8$ all & $t, 2=22.8 \mathrm{~s}$ \\
\hline 相豆伯 & $M_{\alpha}=39.5 \mathrm{aH}$ & $\mathrm{H}_{0}=31$. Lall & $M_{1}=39.4$ mft & $M_{0}=31.10 \mathrm{H}$ \\
\hline 桔合保数 & $k_{u v}=-0,500$, & $k_{0=}=-0.250$ & $k_{u v}=-0.506$, & $k_{0.0}=-0.256$ \\
\hline
\end{tabular}
ことは次のと扔りである。

(1) 二次抵抗は $q$ 軸の值が $d$ 軸の值より大き。

（2）一次自己，二次自己拉よび相互インダクタン

\section{表 2 モー夕定数算定結果}

Table 2. Calculation results of motor constants.
スは $d$ 軸の值が $q$ 軸の値より大きい。

（3）回転形誘導電動機と比較して漏れインダクタ ンスの割合が相対的に大きい。

（4）二次抵抗，漏れインダクタンスに周波数依存 性が若干あり，周波数が高いほうが，前者は大きく， 後者は小さい。

（5）鉄損等価抵抗は，当然周波数依存性が大き く，周波数が高いほうが大きい。

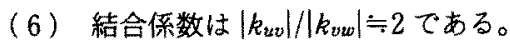

\section{5. 算定結果の検証}

算定した定数が実際の定数と一致しているかどうか を検証するために，算定した定数を用いてシミュレー ションを行い，実験と比較した。

以下のシミュレーションおよび実験は三相一次定格 電圧を印加して行った。

\section{〈5・1〉等価無負荷状態の三相一次電流波形}

非磁性導体板を取外した拘束状態でシミュレーショ

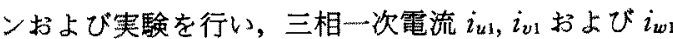
の波形を比較する。図 9 はシミュレーション波形と実 験波形を示したもので，振幅が $1 \%$ 程度前者のほうが 大きいが，上く一致しているといえる。これは（9)式 の定数がよく一致していることを表しており，相互イ ンダクタンスを $v$ 相一次電流だけ流して求めても問 題ないことを示している。なお， $u$ 相一次電流の振幅 は，他の相のそれより $9 \%$ 程度小さい。

〈5・2〉拘束状態の三相一次電流波形非磁性導 体板を取付けた拘束状態で，シミュレーションおよび 実験を行い，三相一次電流 $i_{u 1}, i_{v 1}$ および $i_{w 1}$ の波形を

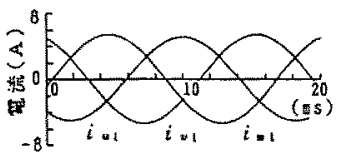

(a) シミュレーション波形

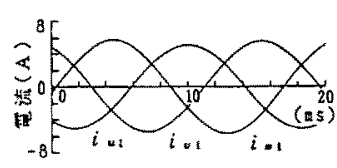

(b) 実験波形
図 9 等価無負荷状態の三相一次電流波形

Fig. 9. Primary-current wave under equivalent no-load state.

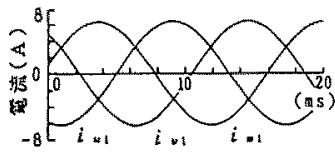

(a) シミュレーション波形

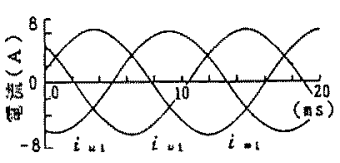

(b) 実駼波形
図 10 拘束状態の三相一次電流

Fig. 10. Primary-current wave under lock state. 


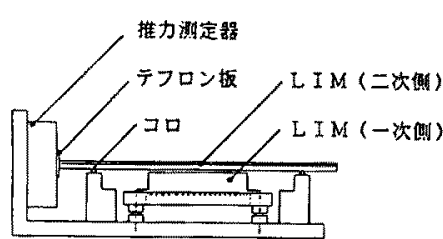

図 11 推力測定の実験装置

Fig. 11. Test system of thrust.

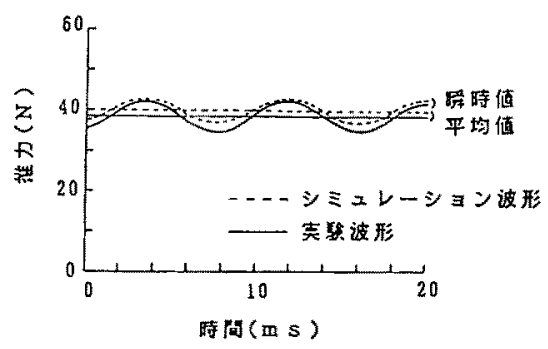

図 12 拘束状態の推力波形

Fig. 12. Thrust wave under lock state.

比較する。図 10 はシミュレーション波形と実験波形 を示したもので、これも $1 \%$ 程度前者のほうが大きい がよく一致しているといえる。これは(5)式の定数 がよく一致していることを表している。なお， $u$ 相一 次電流の振幅は，他の相のそれより $3 \%$ 程度小さい。

〈5・3〉拘束状態の推力滑りが 1 の状態の推力 を，シミュレーション捛よび実験で比較する。英験に よる推力湘定は，LIM を図11に示す推力測定装置に 取付けて行った。推力測定器（KISTLER製，ばね定 数: $2 \mathrm{kN} / \mu \mathrm{m}$, ᄂきい值: $0.01 \mathrm{~N}$ 以下, 固有周波 数： $4 \mathrm{kHz}$ 以上）は压電材料として水晶を用いたもの て、ひずみが非常に小さいのて，推力の過瀿的変化が 直接測定できるのが特徵である。

図 12 は推力のシミュレーション波形と実験波形を 示したもので, 倍周波の脈動がはっきり現れている。 推力の平均值は $3 \%$ 程度, 瞬時值は最大值で $1 \%$ 程度, 最小值で $7 \%$ 程度, 前者のほうが大きいが, 推力とし てはよく一致しているといえる。

以上により，本論文で算定した定数は，推力脈動も 比較的精度良く計算でるものであるいえる。

\section{6.あとがき}

LIM は構造上その定数が非対称であるが，片剈式 短一次形，二層巻，集中巻，全節巻，中性点引出し線 付き，三相 4 極の供試機を例として拘束試験に基つく 非対称性を考慮した定数の算定法を㭘討した。その算 定法は，
（1） LIMを非対称な $d q$ 軸等洒回路で表す。ま た，無解荷状態について非対称な三相等価回路で表 \$。

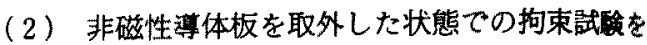
等価無負荷試験とし，その試験を，一次巻線抵抗测定 後, $d$ 軸， $q$ 軸执よU゙一相に別々に一次電死を印加し て行い, $d q$ 軸の鉄損等価抵抗，一次自己インダクタ ンスおよび相互インダクタンスを算定する。相互イン ダクタンスは非対称な結合係数を導入して算定する。

（3）非磁性等体板を取付けた状態での拘束試卧を $d$ 軸および $q$ 軸に別々に一次電圧を印加して行い, $d q$ 軸の二次抵抗，二次自己インダクタンスを算定す る。

以上の算定法により得た定数を用いて，シミュレー ションを行い，三相一次電流および推力について，寒 験と比較し，よく一致していることを確㒛した。

この算定法により得られた非対称定数を用いること により、リニア誘導モータのより高性能な制御ができ るものと期待できる。

(平成 4 年 7 月 3 日受付, 同 4 年 8 月 25 日再受付)

$$
\text { 文献 }
$$

（1）㧾名・大竹，他：「片側式 LIM の T 形等価回路における特性 算定 (1)]. 平 3 電気学会全大, No.811

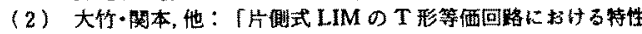
算定 $(2)$ 」. 平 3 同上, No. 812

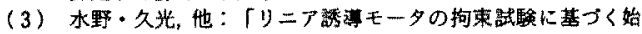
動特性算定法」，重学論 D, 112，172（平 4-2）

（4）松宮・高木：「直線腾运機の端作用ならびに等偭回路につい て1, 䉓学㷫, 91，295，(昭 46-2)

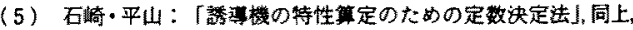
$87,173($ 昭 42-9)

\section{付 録}

$d$ 軸， $q$ 軸および三相の一相分の等価回路は付図 1 のように簡略化される。この図において，係数 $k_{d_{1}}$ $k_{n}$ ，抢よび $k_{\mathrm{I}}$ に対応する係数 $k$ は,

$$
\begin{aligned}
v_{1}= & r_{1} i_{1}^{\prime}+\left(1+r_{1} / r_{i}\right) Z(P) i_{1}^{\prime} \\
& +\left(1+r_{1} / r_{i}\right) e \\
= & r_{1} i_{1}^{\prime}+k Z(P) i_{1}^{\prime}+k e .
\end{aligned}
$$

加，次式で与えられる。

$$
k=1+r_{1} / r_{i}
$$

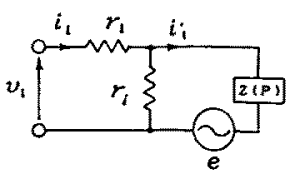

付図 1 一相分の等価回路

app. Fig. 1. Equivalent circuit per phase.

T. IEE Japan, Vol. 113-D, No. 2, '93 


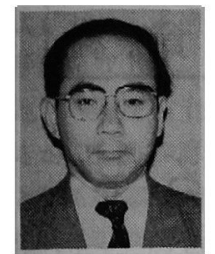

杉 本 英 彦 (正員)

昭和 18 年 6 月 2 日生。 48 年 3 月名古 屋工業大学大学院修士課程修了。34 年 4 月三菱電機 (株) 入社。平成 2 年 4 月福 井大学助教授, 4 年 4 月同教授。工学博 士。平成元年電気学会論文賞受賞。

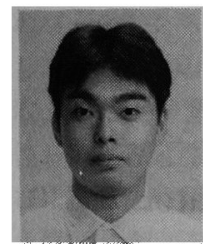

\section{巴正 信（准員）}

昭和 45 年 3 月 18 日生。平成 4 年 3 月 福井大学工学部電子工学科卒業。同年 4 月同大学大学院工学研究科修士課程入 学。電動機制御に関する研究に従事。

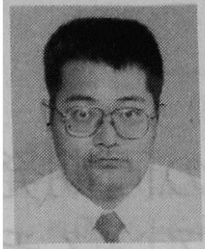

松 村 正 三（正員）

昭和 33 年 1 月 2 日生。 55 年 3 月福井 大学工学部産業機械工学科卒業。同年 4 月福井県工業技術センター入所。リニア モータ，織維機械および工作機械の制御 に関する研究に従事。

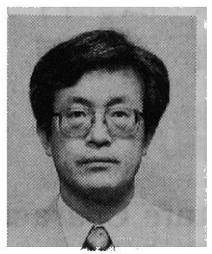

石 井 敏 昭 (正員)

昭和 19 年 7 月 25 日生。 43 年 3 月九 州工業大学制御工学科卒業。同年 4 月三 菱電機 (株) 入社。主として, エレベータ の駆動制御に関する開発に従事。 